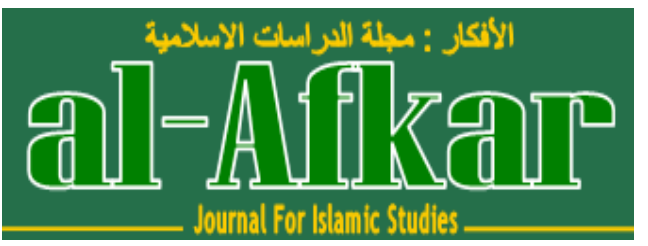

Vol. 2, No. 2, July 2019

P-ISSN : 2614-4883; E-ISSN : 2614-4905

https://al-afkar.com/index.php/Afkar_Journal/issue/view/4

DOI: https://doi.org/10.31943/afkar_journal.v4i1.64

\title{
IMPLEMENTASI PRINSIP SYARIAH TERHADAP PEMBIAYAAN MUDHARABAH PADA BANK SYARIAH MANDIRI KCP INDRAMAYU
}

\author{
Ahmad Syathori \\ Fakultas Agama Islam Universitas Wiralodra Indramayu \\ E-Mail: Ahmadsythorig8@gmail.com
}

\begin{tabular}{|c|c|c|}
\hline Received & Revised & Accepted \\
\hline 3 Juny 2019 & 20 Juny 2019 & 1 July 2019 \\
\hline
\end{tabular}

THE IMPLEMENTATION OF SYARIAH CONCEPT IN MUDHARABAH FUNDING TO MANDIRI SYARIAH BANK IN KCP INDRAMAYU

\begin{abstract}
The research aims to explore the implementation of syariah concept to mudharabah funding Mandiri Syariah Bank in KCP Indramayu. The research was conducted qualitative approach. The data were collected by interview, observation, and documentation. The result showed that the Bank is one financial institution that has an important role in the economy of a country. Global economic developments so rapidly makes the banks could move the economy of a country. One of the Islamic financial institutions are growing rapidly in Indonesia is Islamic banking. Permasalahnya is What in the implementation at Bank Mandiri Syariah Branch Indramayu in accordance with the existing concept in Islamic economics?
\end{abstract}

Keywords: islamic financial institution, syariah banking 


\title{
Ahmad Syathori
}

Implementasi Prinsip Syariah terhadap......

\begin{abstract}
Abstrak
Penelitian ini bertujuan untuk menelusiri implementasi prinsip syariah terhadap pembiayaan mudharabah pada Bank Syariah Mandiri di KCP Indramayu. Penelitian ini dilakukan dengan pendekatan kualitatif. Data dikumpulkan dengan metode wawancara, observasi, dan dokumentasi. Hasil penelitian menunjukan bahwa Bank merupakan salah satu lembaga keuangan yang mempunyai peranan penting di dalam perekonomian suatu negara. Perkembangan perekonomian global yang begitu pesat menjadikan perbankan dapat menggerakkan perekonomian suatu negara. Salah satu lembaga keuangan berbasis syariah yang tengah berkembang pesat di Indonesia adalah perbankan syariah. Permasalahnya adalah Apakah dalam praktik pelaksanaan di Bank Mandiri Syariah KCP Indramayu sesuai dengan konsep yang ada pada ekonomi Islam?
\end{abstract}

Kata kunci : bank syariah, lembaga keuangan islam

\section{Pendahuluan}

Islam sebagai agama samawi yang universal datang dengan sifatnya menangani kehidupan manusia dalam berbagai aspek baik itu dalam aspek spiritual maupun aspek materil. Dalam hal ini Islam berarti agama yang mencakup seluruh hal baik itu sosial, budaya, politik dan ekonomi. Islam sebagai agama universal mencakup tiga pokok utama yaitu akidah, syariah, dan akhlak. Syariah mencakup ibadah mahdhah dan ibadah ghoiru mahdhoh diantara ibadah yang tidak pernah lepas dari setiap kegiatan manusia yaitu dalam aspek ekonomi. Ekonomi adalah kegiatan manusia dalam memenuhi kebutuhannya baik dalam mengkonsumsi maupun memproduksi dengan sumber daya yang ada. ${ }^{1}$

Perkembangan ekonomi syariah di Indonesia ditandai dengan hadirnya Bank Muamalat Indonesia yang resmi beroperasi tahun 1992. Pada saat krisis 1998, bank muamalat sebagai bank syariah pertama bebas bunga mampu bertahan menghadapi krisis yang menimpa Indonesia, dan sejak saat itu bank syariah terus mengalami pertumbuhan yang relatif cepat. Kemudian pada krisis global 2008, bank syariah kembali menunjukkan ketahanannya dengan tidak terlalu terpengaruh imbas krisis tersebut. Pembiayaan yang masih di dominasi pada aktivitas ekonomi domestik dan

tingkat sofistikasi transaksi yang rendah merupakan dua faktor yang dinilai menyelamatkan bank syariah dari krisis. ${ }^{2}$ Hal inilah yang menjadi salah satu penyebab berkembangnya lembaga keuangan syariah hingga sampai saat ini.

Sejak berdirinya Bank Muamalat sebagai pelopor bank yang menggunakan sistem syariah pada tahun 1991, kini banyak bermunculan bankbank syariah, baik yang murni menggunakan sistem tersebut maupun baru pada tahap membuka Unit Usaha Syariah (UUS) atau divisi usaha syariah. Namun

\footnotetext{
${ }^{1}$ Ekonomi Islam Rozalinda, "Teori Dan Aplikasinya Pada Aktivitas Ekonomi Jakarta” (Rajawali Press, 2016).

${ }^{2}$ Sofiniyah Ghufron, “Konsep Dan Implementasi Bank Syari'ah,” Jakarta: Renaisan, 2005.
} 


\section{Ahmad Syathori}

Implementasi Prinsip Syariah terhadap......

keberadaan lembaga keuangan syariah terkhusus bank syariah dalam perbankan nasional baru dikembangkan sejak tahun 1992 yang ditandai dengan berlakunya Undang-Undang RI No. 7 tahun 1992 Tentang Perbankan, yang mulai mengakomodir keberadaan bank syariah. Namun Undang-Undang ini belum memberikan landasan hukum yang cukup kuat terhadap pengembangan bank syariah, karena belum secara tegas mencantumkan prinsip syariah dalam kegiatan usaha bank. ${ }^{3}$

Undang-Undang RI No. 21 Tahun 2008 pasal 2 Tentang Perbankan Syariah menyebutkan bahwa Perbankan Syariah dalam melakukan kegiatan usahanya berasaskan Prinsip Syariah, demokrasi ekonomi, dan prinsip kehati-hatian. ${ }^{4}$ Lalu dalam pasal 1 ayat 12 disebutkan prinsip syariah adalah prinsip hukum Islam dalam kegiatan perbankan berdasarkan fatwa yang dikeluarkan oleh lembaga yang memiliki kewenangan dalam penetapan fatwa di bidang syariah. UndangUndang RI No.1o Tahun 1998 Tentang Perbankan juga menyebutkan mengenai Prinsip Syariah yaitu aturan perjanjian berdasarkan hukum Islam antara bank dan pihak lain untuk

penyimpanan dana dan atau pembiayaan kegiatan usaha, atau kegiatan lainnya yang dinyatakan sesuai dengan syariah, antara lain pembiayaan berdasarkan prinsip bagi hasil (mudharabah), pembiayaan berdasarkan prinsip penyertaan modal (musyarakah), prinsip jual beli barang dengan memperoleh keuntungan (murabahah), atau pembiayaan barang modal berdasarkan prinsip sewa murni tanpa pilihan (ijarah), atau dengan adanya pilihan pemindahan kepemilikan atas barang yang disewa dari pihak bank oleh pihak lain (ijarah wa iqtina). ${ }^{5}$

Nilai-nilai Prinsip Syariah berlandaskan pada nilai-nilai keadilan, kemanfaatan, keseimbangan, dan keuniversalan (rahmatan lil „alamin). diterapkan dalam pengaturan perbankan yang didasarkan pada Prinsip Syariah yang disebut Prinsip Perbankan Syariah. Prinsip Perbankan Syariah merupakan bagian dari ajaran Islam yang berkaitan dengan ekonomi. Salah satu prinsip dalam perbankan syariah yang disebutkan dalam Undang-Undang adalah larangan riba, gharar, maisir, haram dan zalim dalam berbagai bentuknya, dan menggunakan sistem antara lain prinsip bagi hasil. Salah satunya mudharabah Dengan prinsip bagi hasil, Bank Syariah dapat menciptakan iklim investasi yang sehat dan adil karena semua pihak dapat saling berbagi baik keuntungan maupun potensi risiko yang timbul sehingga akan menciptakan posisi yang berimbang antara bank dan nasabahnya. Dalam jangka panjang, hal ini akan mendorong pemerataan ekonomi nasional karena hasil keuntungan tidak hanya dinikmati oleh pemilik modal saja, tetapi juga oleh pengelola modal.

\footnotetext{
${ }^{3}$ Ghufron.

${ }^{4}$ Republik Indonesia, “Undang-Undang No. 21 Tahun 2008," Tentang Perbankan Syariah. Jakarta, 2008.

${ }^{5}$ Bank Indonesia, “Undang-Undang Republik Indonesia No. 10 Tahun 1998 Tentang Perbankan," UndangUndang Republik, 1998.
} 


\section{Ahmad Syathori}

Implementasi Prinsip Syariah terhadap......

Manajemen Bank konvensional dan Bank Syariah pada umumnya memiliki persamaan terutama dalam sisi teknis penerimaan uang, mekanisme transfer, tehnologi komputer yang digunakan, syarat-syarat umum memperoleh pembiayaan, proposal, laporan keuangan dan sebagainya. Namun dengan adanya landasan syariah serta sesuai dengan Peraturan Pemerintah menyangkut Bank Syariah antara lain UU No. 7 tahun 1992 tentang Perbankan sebagaimana telah diubah dengan UU No. 10 tahun 1998 juga terdapat beberapa hal perbedaan diantaranya yang menyangkut aspek legal, struktur organisasi, usaha yang dibiayai, dan lingkungan kerja serta adanya Dewan Pengawas Syariah dalam struktur organisasi serta adanya sistem bagi hasil.

Sistem pemasaran syariah merupakan suatu rangkaian aktivitas produksi barang/jasa dan proses pemesanan produk/jasa kepada konsumen yang sesuai dengan prinsip syariah. ${ }^{6}$ Jadi setiap kegiatan Bank syariah harus tetap mengikuti prinsip syariah yang telah ditetapkan bukan hanya ditetapkan pada produk bank syariah namun juga pada sistem pemasarannya. Dalam dunia pemasaran ada slogan yang menyebutkan tidak ada sesuatu sampai suatu penjualan itu dibuatl hal ini benar adanya karena pentingnya pemasaran itu untuk melakukan aktivitas sesuai target.

Oleh karena itu dalam suatu usaha perlu adanya para pemasar yang andal yang memiliki sikap dan mental yang jujur, kreatif, inovatif, bertanggung jawab, sopan, tenang dan berpikir positif secara konsep tidak ada perbedaan khusus antara konsep pemasaran konvensional dengan syariah namun dalam pemasaran syariah lebih menitikberatkan pada nilai dan norma dari segala serangakaian aktivitas pemasaran. Kegiatan promosi produk dan jasa bank lebih banyak dilakukan melalui media massa cetak dan audiovisual seperti majalah, surat kabar dan televisi yang berupa pengadaan pelatihan, promosi penjualan serta penelitian terhadap pengembangan produk ${ }^{7}$ Jadi dalam pengenalan pengelolaan dan pada bank syariah mereka lebih menitikberatkan pada nilai dan norma pelaku pemasaran itu sendiri melaui ucapan atau dalam istilah disebut word of mouth untuk mengambil kepercayaan dari pihak nasabah, atau pihak bank syariah memberdayakan suatu kelompok tertentu yang telah dibekali pengetahuan tentang bank syariah untuk melakukan penetrasi pasar dikalangan mereka sendiri.

Hermawan kertajaya dalam buku strategi bisnis bank syariah mengatakan bahwa model pemasaran yang ideal untuk perbankan syariah adalah consultative selling dengan tahapan melakukan identifikasi terhadap kebutuhan nasabah, membangun komunikasi yang interaktif dengan semua pihak potensial, memahami produk dan jasa yang ditawarkan berdasarkan sudut pandang nasabah, mendukung bisnis nasabah dalam berbagai situasi serta membina

\footnotetext{
${ }^{6}$ Ikatan Bankir Indonesia, Strategi Bisnis Bank Syariah (Gramedia Pustaka Utama, 2015).

${ }^{7}$ Indonesia.
} 


\section{Ahmad Syathori}

Implementasi Prinsip Syariah terhadap......

hubungan baik yang berorientasi jangka panjang ${ }^{8}$.

Adanya ketidakpercayaan sebagian masyarakat terhadap sistem keuangan syariah untuk mengelola keuangan mereka menjadi salah satu penyebab mengapa masih kurangnya peminat masyarakat terhadap lembaga keuangan syariah dan juga selain itu Selama ini industri perbankan kurang fokus terhadap persoalan manajemen risiko ${ }^{9}$, seperti risiko operasional yang muncul akibat tidak ketatnya pengawasan mengawal prosedur standar operasional. BI telah melakukan peninjauan kembali berbagai kebijakan perbankan karena selama ini hanya fokus pada kesehatan bank namun melupakan masalah-masalah operasional.

Oleh karena itu perlu pengetahuan yang lebih mendalam mengenai bagaimanakah penerapan prinsip ekonomi Islam terhadap lembaga keuangan syariah terkhusus pada Bank-Bank Syariah sebagai lembaga keuangan pertama yang menerapkan sistem Prinsip syariah apakah penerapannya sudah sesuai dengan peraturan dan ketentuan yang ada atau tidak, karena masih kurangnya representasi bank-bank syariah terhadap penerapan prinsip ekonomi Islam dalam produk pengelolaan dana bank-bank syariah kepada masyarakat menjadikan masih banyaknya masyarakat yang belum bisa dan masih meragukan pengelolaan dana mereka kepada lembaga keuangan syariah terkhusus bank-bank syariah. Selain itu keraguan masyarakat terhadap bank-bank syariah dalam menghadapi resiko keuangan yang besar masih belum bisa diminimalisir. Permasalahan dalam suatu lembaga keuangan tidak akan timbul jika tidak dari penerapan pengelolaan kebijakan yang tidak sesuai dengan prinsip yang sudah ditetapkan.

\section{Metode Penelitian}

\section{Lokasi dan Jenis Penelitian}

Lokasi dan objek penelitian ini adalah dilakukan di Indramayu dengan objek penelitian Bank Syariah Mandiri, untuk memperoleh informasi dan data mengenai pelaksanaan prinsip syariah yang terdapat di bank syariah dan faktorfaktor apa saja yang menjadi kelemahan bank syariah sehingga menyebabkan kurangnya peminat masyarakat terhadap perbankan syariah dan yang terpenting adalah mendapatkan informasi atau data yang akurat mengenai pelaksanaan prinsip syariah terhadap perbankan syariah di Indramayu.

Penelitian ini menggunakan penelitian kualitatif Jenis studi kasus yang diharapkan dapat memberikan gambaran yang menyeluruh dan sistematis tentang fakta yang berhubungan dengan prinsip syariah terhadap perbankan syariah Mandiri di Indramayu. Proses penelitian dilakukan secara intensif, terinci dan memberikan gambaran mendalam terhadap seseorang, kelompok, suatu

\footnotetext{
${ }^{8}$ Ibnudin Ibnudin, "PRINSIP PENGELOLAAN LIKUIDITAS BANK SYARIAH," Risâlah, Jurnal Pendidikan Dan Studi Islam 3, no. 1 (2016): 70-77.

${ }^{9}$ Abd Muin and Ahmad Khotibul Umam, "EKSISTENSI KOMPILASI HUKUM ISLAM DALAM SISTEM HUKUM POSITIF," Risâlah, Jurnal Pendidikan Dan Studi Islam 3, no. 1 (2016): 63-77.
} 


\section{Ahmad Syathori}

Implementasi Prinsip Syariah terhadap......

organisasi atau lembaga terhadap fenomena-fenomena tertentu yang bertujuan untuk memberikan pandangan yang lengkap dan mendalam mengenai subyek yang diteliti. Dengan demikian Penelitian studi kasus, lebih mengutamakan observasi, wawancara dan dokumentasi.

Jenis Data

Penelitian ini bercorak field research, oleh karena itu jenis data yang digunakan dalam penelitian ini adalah bersifat kualitatif. Pengumpulan data ini dilakukan dengan cara wawancara terhadap beberapa responden yang berhubungan dengan masalah yang akan diteliti dengan cara mengajukan beberapa pertanyaan kepada responden yang berhubungan dengan masalah yang akan diteliti.

Sumber Data

Adapun sumber data yang digunakan dalam pengumpulan data dalam penelitian ini yaitu:

a. Data Primer

Data primer adalah data yang diperoleh secara langsung dari pihak yang terkait. Data ini penulis peroleh dari dengan mendatangi sumber-sumber data yang relevan dengan masalaha penelitian.

b. Data Sekunder

Data ini diperoleh dengan cara membaca beberapa literatur atau bahan bacaan yang berkaitan dengan judul penelitian, dalam hal ini bahan-bahan penelitian yang terkait dengan kepustakaan adalah:

1) Undang-Undang nomor 10 tahun 1998 tentang Perbankan (perubahan pertama Undang-Undang nomor 7 tahun 1992 tentang Perbankan

2) Undang-Undang RI nomor 21 tahun 2008 tentang Perbankan Syariah

3) Fatwa Dewan Syariah Nasional

Metode Pengumpulan Data

Wawancara

Wawancara digunakan sebagai teknik pengumpulan data apabila peneliti ingin melakukan studi pendahuluan untuk menemukan permasalahan yang akan diteliti dan jika peneliti ingin mengetahui hal-hal yang lebih mendalam dari responden. Dengan demikian wawancara dilakukan dengan pertanyaan yang "Open ended" (wawancara yang jawabannya tidak terbatas pada satu tanggapan saja) dan mengarah pada pedalaman informasi serta dilakukan tidak secara formal terstruktur. ${ }^{10}$ Dalam hal ini

\footnotetext{
${ }^{10}$ Dedi Mulyana, Metode Penelitian Kualitatif (Cet. I;Bandung: PT. Remaja Rosdakarya, 2002),
} 
peneliti akan melakukan wawancara dengan para pegawai dilingkungan Bank Syariah Mandiri di Indramayu guna memperoleh informasi mengenai hal-hal yang berhubungan dengan pelaksanaan prinsip syariah terhadap perbankan syariah di Indramayu.

Dokumentasi

Tehnik pengumpulan data menggunakan dokumentasi dengan cara mengumpulkan bahan-bahan pustaka baik yang berupa buku-buku literatur maupun dokumen-dokumen. Disini yang penulis maksud adalah data-data yang didapatkan dari Bank Syariah Mandiri di Indramayu. Dokumen merupakan catatan peristiwa yang sudah berlalu, baik dalam bentuk tulisan, gambar, atau karya-karya yang monumental. Dokumen yang berbentuk tulisan seperti Akte, peraturan, kebijakan, dan lain-lain. Dokumen yang berbentuk gambar seperti foto, video dan lain sebagainya.Teknik pengumpulan data dengan dokumen adalah merupakan pelengkap dari penggunaan metode observasi dan wawancara dalam penelitian kualitatif".

\section{Hasil dan Pembahasan}

\section{Penerapan Pembiayaan Mudharabah Dalam Perbankan Syariah}

Dalam Kompilasi Hukum Ekonomi Syari'ah disebutkan bahwa Mudharabah adalah kerjasama antara pemilik dana atau penanam modal dengan pengelola modal untuk melakukan usaha tertentu dengan pembagian keuntungan berdasarkan nisbah. ${ }^{12}$

Sebagaimana yang telah disebutkan di atas bahwa perjanjian pembiayaan mudharabah merupakan perjanjian kerjasama antara pemilik modal dengan pengelola usaha, yang mana di dalam akad tersebut dinyatakan akan membagi keuntungan di antara mereka, atau perjanjian atas suatu jenis perkongsian dimana pihak pertama menyediakan dana dan pihak kedua bertanggung jawab atas pengelolaan usaha $^{13}$. Maka dapat dipahami bahwa perjanjian mudharabah didasarkan kepada kepercayaan dengan pengertian lain bahwa pemodal akan menyerahkan dananya kepada pihak pengelola dana setelah pemodal merasa yakin bahwa peminjam modal tersebut baik secara keahlian maupun moral dapat dipercaya untuk mengelola modal yang diberikan dengan keahliannya dan tidak akan memanipulasi modal tersebut.

Pembiayaan mudharabah di Bank Syariah Watampone tidak terlepas dari mekanisme pelaksanaan perjanjian yang telah ditetapkan berdasarkan syarat dan

\footnotetext{
${ }^{11}$ Sugiyono, Metode Penelitian Pendidikan:(Pendekatan Kuantitatif, Kualitatif Dan R \& D) (Alfabeta, 2008).

${ }^{12}$ Republik Indonesia, Kompilasi Hukum Ekonomi Syari“ah, Buku II, BAB I, Pasal 20.

${ }^{13}$ Sasa Sunarsa, "TAFSIR THEORY; STUDY ON AL-QURAN METHODS AND RECORDS.(TEORI TAFSIR; KAJIAN TENTANG METODE DAN CORAK TAFSIR AL-QURAN)," Al-Afkar, Journal For Islamic Studies 3, no. 1 (2019): 247-59.
} 


\section{Ahmad Syathori}

Implementasi Prinsip Syariah terhadap......

rukun dalam akad, sesuai dengan yang dikemukakan oleh ulama fiqhiyah dan juga Dewan Syariah Nasional MUI tentang mudharabah. Oleh karena itu keabsahan suatu perjanjian pembiayaan mudharabah tidak terlepas dari pada pemenuhan syarat dan rukun mudharabah itu sendiri. Tahapan proses pembiayaan diawali dengan:

1. Pemenuhan syarat dan rukun
a. Ada pemilik dana yang cakap hukum
b. Ada pengelola yang cakap hukum
c. Ada modal (uang/barang) yang dibayar tunai yang jelas jumlah dan jenisnya
d. Modal diserahkan sepenuhnya kepada pengelola secara langsung
e. Ada akad
f. Ada kesepakatan bagi hasil
g. Ada usaha yang dibiayai halal

2. Proses pembiayaan
a. Identitas diri dan pasangan
b. Kartu keluarga dan surat nikah
c. Copy rekening bank 3 bulan terakhir
d. Akte pendirian usaha
e. Identitas pengurus
f. Legalitas usaha
g. Laporan keuangan 2 tahun terakhir
h. Past performance 2 tahun terakhir
i. Rencana usaha 12 bulan yang akan datang
j. Data obyek pembiayaan

3. Analisa pejabat bank
a. Wawancara
b. Kunjungan lapangan (call visit)
c. Laporan kunjungan (call report)

4. Persetujuan pembiayaan

5. Bila pihak bank setuju maka pihak pejabat bank membuat persetujuan prinsip bersyarat (officer letter)

6. Bila nasabah setuju terhadap officer letter maka akan dilanjutkan dengan pengikatan pembiayaan dan jaminan 


\section{Ahmad Syathori}

Implementasi Prinsip Syariah terhadap......

7. Pencairan pembiayaan

8. Monitoring

9. Pelunasan

Dilihat dari banyaknya proses yang harus ditempuh untuk mendapatkan pembiayaan ini dapat membuktikan bahwa cukup untuk diberikan dan dilanjutkan melakukan Namun pada satu sisi, sangat sulit untuk menentukan amanah atau tidaknya calon nasabah/mudharib tersebut sebagaimana ${ }^{14}$ yang dikriteriakan Bank Syariah Mandiri Cabang Medan sebab amanah itu tidak bisa diukur dengan bagus dan aktifnya pelaporan yang diberikan nasabah/mudharib.

Dalam pelaksanaannya Bank syariah menerapkan beberapa prinsip sebagai landasan dalam kegiatan perbankan yaitu:

a. Pembayaran terhadap pinjaman dengan nilai yang berbeda dari nilai pinjaman dan ditentukan sebelumnya tidak diperbolehkan.

b. Pemberi dana harus turut berbagi keuntungan dan kerugian sebagai akibat hasil usaha institusi yang meminjam dana

c. Islam tidak membolehkan -menghasilkan uang dari uang\| uang hanya sebagai media pertukaran dan bukan komoditas karena tidak memiliki nilai intrinsik

d. Unsur ghrarar (ketidakpastian, ketidakjelasan) tidak diperkenankan. Kedua belah pihak harus mengetahui dengan baik hasil yang akan mereka peroleh dari sebuah transaksi.

e. Investasi hanya boleh diberikan pada usaha-usaha yang tidak diaharamkan dalam Islam. Seperti usaha minuman keras yang tidak boleh didanai oleh perbankan syariah.

Dalam pembagian keuntungan atau nisbah dari pihak bank telah menentukan besar kecil pembagian keuntungan atau proporsi keuntungannya dan jelas persentasenya sebagai berikut:

\begin{tabular}{|l|l|}
\hline NASABAH & BANK \\
\hline $51 \%$ & $48 \%$ \\
\hline $50 \%$ & $46 \%$ \\
\hline $60 \%$ & $40 \%$ \\
\hline
\end{tabular}

Untuk lebih jelas berikut bagan mengenai transaksi Pembiayaan Mudharabah Keuntungan harus dibagi untuk kedua belah pihak, yaitu investor (pemilik modal)

\footnotetext{
${ }^{14}$ Asep Arsyul Munir, "AGAMA, POLITIK DAN FUNDAMENTALISME," Al-Afkar, Journal For Islamic Studies 1, no. 1 (2018): 149-69.
} 
dan pengelola (mudharib). Selain itu Break Even Point (BEP) harus jelas, karena BEP menggunakan sistem revenue sharing dengan profit sharing berbeda.

Dari hasil wawancara dari salah satu pegawai Bank Syariah mereka mengatakan bahwa perbedaan mendasar antara revenue sharing dan profit sharing ialah Revenue sharing adalah pembagian keuntungan yang dilakukan sebelum dipotong biaya operasional, sehingga bagi hasil dihitung dari keuntungan kotor/ pendapatan. Sedangkan profit sharing adalah pembagian keuntungan dilakukan setelah dipotong biaya operasional, sehingga bagi hasil dihitung dari keuntungan bersih. $^{15}$

Jadi untuk pembagian keuntungan pada bank syariah belum ada kepastian apakah akan memakai Revenue sharing atau profit sharing dalam hal pembagian keuntungan hal ini akan diputuskan dilihat seberapa besar keuntungan yang akan diperoleh terhadap hasil usaha tersebut.

\section{Analisis Implementasi Keadilan Yang Diharapkan}

Keadilan adalah salah satu prinsip yang penting dalam mekanisme perekonomian Islam. Bersikap adil dalam ekonomi tidak hanya didasarkan pada ayat- ayat Al-Qur'an atau Sunnah Rasul, tetapi juga berdasarkan pada pertimbangan hukum alam, dimana alam diciptakan berdasarkan atas prinsip keseimbangan dan keadilan. Adil dalam ekonomi bisa diterapkan dalam penentuan harga, kualitas produk, perlakuan terhadap pekerja, dan dampak yang timbul dari berbagai kebijakan ekonomi yang dikeluarkan.

Berdasarkan nilai prinsip syariah yang sangat ditekankan dalam pelaksanaan kegiatan muamalah pada bank syariah, merupakan titik acuan yang menjadi perbedaan yang sangat urgen antara Bank Syariah dan Bank Konvensional. Prinsip keadilan sangat ditekankan dalam kehidupan bermuamalah, keadilan sebagai salah satu nilai dasar kekuatan hukum merupakan landasan dalam membuat kesepakatan yang akan dituangkan dalam suatu akad atau perjanjian, kesepakatan yang harus dibuat oleh bank haruslah kesepakatan yang seimbangnya hak setiap pihak sebagai bentuk keadilan.

Keadilan bukanlah sesuatu yang hanya dianggap sebagai sebuah nilai belaka akan tetapi keadilan itu haruslah diimplementasikan sehingga menjadi sebuah bentuk yang nyata pada pembiayaan mudharabah sebagai bentuk bagi hasil yang seimbang, dengan segala hal baik keuntungan maupun tanggungan kerugian yang didapatkan sesuai dengan kesepakatan yang dibuat.

Keadilan yang diterapkan terlihat sangat mencolok ketika penentuan perjanjian bagi hasil yang disepakati pada awal perjanjian, pada bagian syarat dan rukun akad, akan tetapi kesepakatan tersebut harus dilihat dan dianalisis terlebih

\footnotetext{
${ }^{15}$ Ana (25 tahun), Customer Service, wawancara, Watampone, 11 Maret 2017.
} 
dulu oleh bank dari segi bisnis yang diajukan dan manajemen resikonya sehingga pihak bank dapat memperhitungkan segala resiko yang akan terjadi kedepannya. Penetapan mengenai bagi hasil ini sudah berdasarkan perhitungan sebelah pihak saja dari hal ini saja sudah nampak ketidakseimbangan dalam pembuatan kesepakatan karena adanya unsur satu pihak saja sudah membuat nilai keadilan itu berkurang yang seharusnya diterapkan dalam suatu akad atau perjanjian.

Pada konsep keadilan memberikan gambaran titik awalnya dari format akad yang dibuat harus memberikan rasa keadilan dengan adanya proses tawarmenawar yang artinya ada proses transparansi pada akad kontrak yang dibuat hingga kedua belah pihak lebih mengetahui proporsi hitungan bagian yang akan dibagikan dengan menggunakan sistem profit sharing atau revenue sharing. Jika ditelaah lebih jauh dalam praktiknya seperti yang telah dijelaskan sebelumnya bahwa penentuan bagi hasil yang telah jelas ditentukan oleh pihak bank diawal perjanjian membuat nasabah tidak memiliki kekuasaan lebih dalam menentukan keuntungan yang akan dibagi pada akhirnya nasabah secara mau tidak mau akan mengikuti prosedur yang telah dicantumkan terlebih dahulu, selain itu faktor kurang pahamnya nasabah mengenai pengetahuan tentang proses bermuamalah menjadi tambahan poin bahwa masih adanya pihak yang belum mendapat keadilan secara merata.

Secara hukum syari, akad yang tertuang dalam formulir yang disediakan pihak bank cukup transparan dan lahiriahnya tidak ada masalah karena Bank Syariah sangat terkait dengan akad-akad muamalah syari'ah. Bank konvensional tidak terikat dengan aturan manapun. Selain itu karena Bank syariah menerapkan prinsip mudharabah, sehingga bagi hasil tergantung pada:

1. Pendapatan bank (hasil/laba usaha)

2. Nominal deposito nasabah

3. Nisbah (persentase) bagi hasil antara nasabah dan bank

4. Jangka waktu deposito

Dengan pembagian profit sharing dan revenue sharing maka terpampang jelas bahwa dalam Bank Syariah terkandung dimensi keadilan dan pemerataan, lain halnya dengan Bank Konvensional dengan sistem bunga memandang dan memberlakukan bahwa kekayaan yang dimiliki peminjam menjadi jaminan atas pinjamannya apabila terjadi kerugian terhadap usaha yang didanai, maka kekayaan peminjam modal akan disita menjadi hak milik pemodal (Bank), sementara dalam bank syariah kelayakan usaha yang akan didanai menjadi jaminan oleh karena hal itulah mengapa keuntungan dan kerugian akan ditanggung bersama.

Namun jika pada kenyataannya berdasarkan narasumber yang saya wawancarai sebagai salah satu nasabah pada bank syariah pak Salim Said mengatakan bahwa sulit untuk mengajukan pembiayaan mudharabah kepada bank syariah secara fakta beliau pernah mengajukan namun tidak diterima oleh pihak 


\section{Ahmad Syathori}

Implementasi Prinsip Syariah terhadap......

bank syariah karena terlalu sulitnya proses yang dilalui dan beliau bukan nasabah pada bank yang bersangkutan ${ }^{16}$ hal ini mengindikasikan bahwa ada unsur ketidakadilan dalam memberikan pelayanan kepada orang yang meminta pembiayaan.

Dari wawancara dengan salah satu customer service Secara prinsip mudharabah yang syarii, kerugian yang terjadi selama bukan karena kelalaian dan kecerobohan mudharib maka murni ditanggung pemodal, dalam hal ini adalah bank. mudharib tidak dibebani apapun kecuali dia rugi tidak dapat laba dari usaha tersebut. Praktik yang terjadi di dunia bank syariah cukup beragam. ${ }^{17}$ Perlu diketahui, bahwa

ternyata hampir semua bank mempersyaratkan pada akad mudharabah semua asset nasabah yang digunakan untuk usaha harus diasuransikan terlebih dahulu. Ini sebagai upaya pengamanan bilamana terjadi sesuatu di luar prediksi semua pihak.Melihat hal ini ini tidak dapat dikatakan sebagai mudharabah karena tidak ada keadilan dalam menanggung kerugian, sama halnya ialah pihak nasabah hanya meminjam dari bank dengan memberikan jaminan berupa aset yang dapat diambil jika menasabah mengambil kerugian. Hal ini tidak lagi sejalan dengan konsep syari'ah karena konsep syariah mengajarkan menyangga usaha secara bersama baik- baik dalam mebagi keuntungan atau sebaliknya, hal ini dapat dimulai dengan

transparansi dalam membuat kontrak, penghargaan terhadap waktu, amanah, bila semua hal itu terpenuhi maka akan menghasilkan perjanjian dengan kualitas terbaik.

\section{Langkah-langkah Pengenalan Sistem Prinsip Syariah Kepada Nasabah}

Dalam pelaksanaannya Bank Syariah untuk mempersentasikan prinsip syariahnya pihak bank hanya melakukan dalam lingkup internal, berikut langkah sosialisasi yang dilakukan oleh Bank Syariah dalam mengenalkan sistem prinsip syariah:

1. Melakukan pembukaan forum antara nasabah dan bank

2. Memperkenalkan produk - produk yang ada dalam bank itu sendiri

3. Memberikan kesempatan kepada nasabah untuk melakukan umpan balik.

Dapat dilihat jelas bahwa untuk langkah sosialisasi yang diambil oleh pihak bank masih sekedar lingkup internal saja, pihak bank akan memberikan sosialisasi hanya kepada nasabah dan calon nasabah pihak bank belum melakukan kegiatan eksternal guna mensosialisasikan sistem syariahnya berupa pengadaan seminar, ataupun

\footnotetext{
${ }^{16}$ Salim Said (53 tahun), Pemilik Percetakan Offset, wawancara, Watampone, 10 Maret 2017.

${ }^{17}$ Efi Hardianti (25 tahun), Teller, wawancara, Watampone, 11 Maret 2017.
} 


\section{Ahmad Syathori}

Implementasi Prinsip Syariah terhadap......

promosi secara langsung dan masih kurangnya promosi melalui media cetak ataupun media online. Oleh karena itulah mengapa bank syariah masih belum mampu menarik nasabah secara massal untuk beralih dari bank konvensional ke bank syariah meski pada kenyataannya tidak dapat dipungkiri bahwa peningkatan nasabah masih ada meski tidak terlalu signifikan.

\section{Langkah-langkah Dalam Mengurangi Resiko Yang Terjadi}

Pada prinsipnya kerugian yang terjadi pada kegiatan usaha yang tidak dapat dihindari karena di luar kekuasaan manusia (over macht), sepenuhnya ditanggung oleh pemilik modal (shahibul maal) dalam hal ini Bank, sedangkan kerugian yang disebabkan oleh kelalaian nasabah atau mudharib dalam mengelola usaha, penyelewengan penyalah-gunaan modal atau menunda-nunda pembayaran maka kerugian ditanggung oleh nasabah/ mudharib.

Tidak dapat dipungkiri bahwa dalam setiap muamalah apalagi terhadap muamalah bank yang menyangkut tentang uang pasti akan menghadapi yang namanya resiko. Undang-Undang No.21 Tahun 2008 tentang Perbankan Syariah Pasal 1 angka (26) menyebutkan bahwa agunan adalah jaminan tambahan, baik berupa benda bergerak maupun benda tidak bergerak yang diserahkan oleh pemilik agunan kepada bank syariah dan atau unit usaha syariah guna menjamin pelunasan kewajiban nasabah yang difasilitasi ${ }^{18}$

Dalam fiqh Islam tidak dituntut untuk meminta jaminan kepada nasabah/mudharib, akan tetapi bank-bank syariah pada umumnya meminta berupa bentuk jaminan, hal ini dilakukan pihak bank syariah untuk menegaskan jaminan tersebut ada hanya untuk memastikan kembalinya modal, sebab dana yang diberikan kepada nasabah/mudharib itu adalah pada umumnya dana yang dihimpun dari masyarakat luas.

Sebagaimana disebutkan dalam Keputusan Fatwa Dewan Syariah Nasional No.07/DSN-MUI/IV/20oo Tentang Pembiayaan Mudharabah dinyatakan bahwa pada prinsipnya dalam pembiayaan Mudharabah tidak ada jaminan, namun agar mudharib tidak melakukan penyimpangan, Lembaga Keuangan Syariah dapat meminta Jaminan dari Mudharib atau pihak ketiga. Jaminan ini hanya dapat dicairkan apabila mudharib terbukti melakukan pelanggaran terhadap hal-hal yang telah disepakati bersama dalam akad ${ }^{19}$

Berdasarkan dari kedua aturan diatas yang telah disebutkan jelas bahwa jaminan atau agunan hanya sebagai langkah antisipasi akan tetapi dalam prakteknya pada Bank Syariah ketika terjadi resiko yang tidak diinginkan maka jaminan atau agunan yang menjadi jaminan pada saat akad akan menjadi milik

\footnotetext{
${ }^{18}$ Undang-Undang No.21 Tahun 2008 Tentang Perbankan Syari‘ah BAB I Pasal 1.

${ }^{19}$ Dewan Syariah Nasional, Keputusan Fatwa Dewan Syariah Nasional No.07/DSN- MUI/IV/2000 Tentang Pembiayaan Mudharabah.
} 


\section{Ahmad Syathori}

Implementasi Prinsip Syariah terhadap......

bank hal ini tidak lagi menjadi adil bagi pihak yang rugi karena pada praktiknya akan sulit menemukan solusi terbaik dalam memecahkan permasalahan resiko dan pada akhirnya jaminan yang dijaminkan akan berpindah hak kepemilikan dalam menebus modal biaya yang telah dipakai dan ini tidak lagi sesuai dengan langkah yang ditempuh agar resiko yang terjadi tidak menimbulkan dampak besar atau istilah lain langkah antisipasi yang diambil ialah:

1. Melakukan kembali sistem sosialisasi dalam peninjauan terhadap permasalahan yang dihadapi

2. Menyampaikan peringatan berupa peringatan lisan kepada nasabah

3. Memberikan solusi yang terbaik kepada nasabah

4. Memberikan keputusan dan melanjutkan transaksi dalam pelelangan barang jaminan.

Untuk nasabah yang mengalami kerugian pada poin ketiga diatas menunjukkan bahwa pihak bank akan memberikan solusi yang terbaik namun pada ahirnya ketika tidak tercapai kesepakatan maka keputusan selanjutnya ialah melakukan pelelangan pada barang jaminan, secara tidak langsung pada teorinya mengatakan jaminan merupakan sesuatu yang dijaminkan agar pengelola usaha yang mengalami resiko tidak lari dari pembayaran utang bukan untuk membayarkan utang ganti rugi.

\section{Simpulan}

Setelah penyusun menjabarkan dan menganalisis skripsi ini, maka penyusun dapat mengambil kesimpulan sebagai berikut:

1. Pelaksanaan pembiayaan mudharabah di bank syariah dilakukan dengan cara teratur dan berkekuatan hukum sehinnga dapat memberikan rasa aman kepada kedua belah pihak itu sudah sesuai dengan prinsip syariah

2. Dalam penerapan prinsip syariahnya terhadap kegiatan perbankan bank syariah belum mampu menerapakan secara keseluruhan dari segi teori bank syariah sangat menarik minat namun dalam praktiknya banyak yang belum dapat terealisasi

3. Masih belum transparansinya pihak bank syariah dalam memberikan informasi kepada masyarakat akibat masih kurangnya SDM yang mumpuni dan profesional di bidangnya. Sehingga masih banyak masyarakat yang belum mengetahui mengenai mudharabah ini 


\section{Ahmad Syathori}

Implementasi Prinsip Syariah terhadap......

\section{DAFTAR PUSTAKA}

Ghufron, Sofiniyah. "Konsep Dan Implementasi Bank Syari’ah.” Jakarta: Renaisan, 2005.

Ibnudin, Ibnudin. "PRINSIP PENGELOLAAN LIKUIDITAS BANK SYARIAH." Risâlah, Jurnal Pendidikan Dan Studi Islam 3, no. 1 (2016): 70-77.

Indonesia, Bank. "Undang-Undang Republik Indonesia No. 10 Tahun 1998 Tentang Perbankan." Undang-Undang Republik, 1998.

Indonesia, Ikatan Bankir. Strategi Bisnis Bank Syariah. Gramedia Pustaka Utama, 2015.

Indonesia, Republik. "Undang-Undang No. 21 Tahun 2008." Tentang Perbankan Syariah. Jakarta, 2008.

Muin, Abd, and Ahmad Khotibul Umam. "EKSISTENSI KOMPILASI HUKUM ISLAM DALAM SISTEM HUKUM POSITIF." Risâlah, Jurnal Pendidikan Dan Studi Islam 3, no. 1 (2016): 63-77.

Munir, Asep Arsyul. "AGAMA, POLITIK DAN FUNDAMENTALISME." Al-Afkar, Journal For Islamic Studies 1, no. 1 (2018): 149-69.

Rozalinda, Ekonomi Islam. "Teori Dan Aplikasinya Pada Aktivitas Ekonomi Jakarta." Rajawali Press, 2016.

Sugiyono. Metode Penelitian Pendidikan:(Pendekatan Kuantitatif, Kualitatif Dan R E D). Alfabeta, 2008.

Sunarsa, Sasa. "TAFSIR THEORY; STUDY ON AL-QURAN METHODS AND RECORDS.(TEORI TAFSIR; KAJIAN TENTANG METODE DAN CORAK TAFSIR AL-QURAN)." Al-Afkar, Journal For Islamic Studies 3, no. 1 (2019): 247-59.

Antonio, Muhammad Syafi'i. Bank Syariah Wacana Ulama dan Cendikiawan.

Jakarta: Tazkia Institute, 1999.

Dewi, Gemala. Aspek-Aspek Hukum Dalam Perbankan dan Perasuransian Syariah di Indonesia. Jakarta: Prenada Media Group, 2004.

Departemen Agama. Al-Qur"an dan Terjemahnya. Bekasi: Dua Sukses Mandiri, 2002.

Ekonomi Islam, Ekonomi Islam Teori dan Aplikasinya pada Aktivitas ekonomi

Jakarta: Rajawali Pers, 2014.

Himpunan Fatwa Dewan Syariah Nasional. Ed. 2. Cet. 2. Jakarta: DSN-MUI dan Bank Indonesia, 2003.

http://www.ruangdiskusi.com.pdf.

Harahap, Yahya. Segi-Segi Hukum Perjanjian. Bandung:1986. 
Heri Sudarsono, Bank dan Lembaga Keuangan Syariah. Ekosiana, Kampus Fakultas Ekonomi UII, Yogyakarta: 2007.

K, Amirudin. Dasar-Dasar Ekonomi Islam. Makassar: Alaudiin University Press, 2014.

Manan, Abdul. Hukum Ekonomi Syariah Dalam Perspektif Kewenangan Peradilan Agama. Jakarta: 2016.

Mulyana, Dedi, Metode Penelitian Kualitatif. Bandung: PT. Remaja Rosdakarya,2002 